\title{
Analysis of Risk Factors in the Korean Repo Market: Based on the US and European Repo Market Experiences
}

\author{
Sung-guan Yun* \\ Ronald Heijmans**
}

The views expressed herein are those of the authors and do not necessarily reflect the official views of the Bank of Korea. When reporting or citing this paper, the authors' name should always be stated explicitly.

\footnotetext{
* Payment Systems Research Team, Payment \& Settlement Systems Department, The Bank of Korea, E-mail: sg.yun@bok.or.kr

** Oversight Department, Cash and Payment Systems Division, De Nederlandsche Bank, E-mail: ronald.heijmans@dnb.nl
} 


\section{Contents}

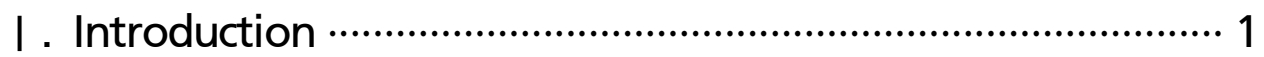

II. Comparison between US and European Repo Markets … 2

1. Definitions

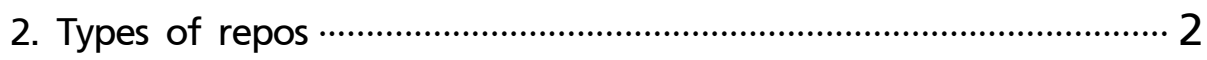

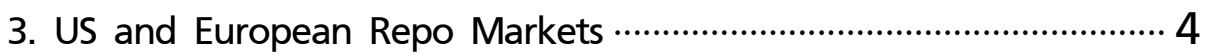

4. Experiences of the Global Financial Crisis ………………………..... 9

III. Conditions of Korean Repo Market, and Concerns …..... 15

1. Conditions of Korean Repo Market ……………………………. 15

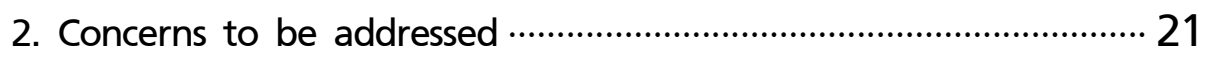

IV . Summary and Policy Implications ……........................... 29

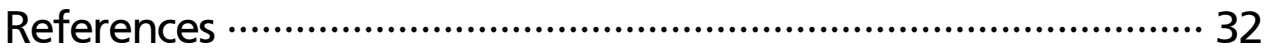




\section{Analysis of Risk Factors in the Korean Repo Market: Based on the US and European Repo Market Experiences}

Repo markets had been deemed more resilient against market instability compared to the unsecured inter-bank loan markets. In the US and Europe, however, prolonged investor runs on repos developed during the global financial crisis. Furthermore, in the course of the evolution of the crisis, the repo markets in the US and Europe showed differing movements.

In contrast, no risks arising from the Korean repo market have yet emerged in practice thanks in part to its small market volume during the global financial crisis, but it could give rise to significant risks due to some fragility arising from factors such as the increase of trade concentration. For this reason, we wish to identify some weak points, and suggest some areas for improvement such as a ceiling on the amount of borrowing, and on the proportion of illiquid collateral held by investors.

In addition, we discuss the need for the greater differentiation of margin, and for the extension of the intraday repo facility to the repo market.

Keywords: Clearing, Repo, Settlement risk, OTC bonds

JEL Classification: E42, G23 


\section{Introduction}

The US and European repo ${ }^{1)}$ markets started growing from the early 2000s, but suffered a great deal of instability during the global financial crisis. The markets had been deemed more resilient against market instability compared to the unsecured inter-bank loan markets, since collateral could be seized if the borrower defaulted. Contrary to this expectation, however, there turned out to be prolonged investor runs on repos during the crisis.

In contrast, the Korean repo market has not received attention during the crisis, because of its small market size relative to that of the call market. Korean institutional repos ${ }^{2}$ ) have recently shown rapid growth, due to the increase in eligible securities utilized as collateral with the development of the Korean bond markets and to government measures to improve the trading market and cap the amount of call borrowings by securities companies.

During the crisis, the importance of this market became clear. In Europe, lenders increasingly preferred lending in the repo market instead of in the unsecured market $(\mathrm{ECB}, 2010)$ as the loan is secured by collateral in case of the counter-party's failure. In US, due to the increased uncertainty on the valuation of collaterals, investors' flight-to-safety behavior resulted in the dysfunction of bilateral repo markets (Gorton and Metrick, 2011).

The smooth functioning of the repo markets is of interest to central banks in that they facilitate monetary policy transmission to the bond markets, for example, by banks or securities companies' financing through the short-term money markets

1) A repo market is one of the money markets through which financial companies adjust their surpluses and shortages of short-term money. The market is distinguished from other money markets(e.g. interbank unsecured loans, CDs(Certificates of Deposit), and CP(Commercial Paper)) in that borrowers (securities selling parties) can borrow money while securing the return of their securities, and that investors (money lending parties) can invest safely by holding title to the collateral provided in the trades.

2) There are three repo markets in Korea, differentiated by market participant type: the customer repo market for trades between customers and financial firms, the institutional repo market for trades between firms, and the BOK repo market for trades between the BOK and financial firms. In our analysis we exclude both the customer and the BOK repo markets, because the customer repo market was built and continues to function to provide customer-deposit products for financial firms, and the BOK repo market is utilized for the purpose of central bank's open market operations. 
for their investment in the bond markets. Furthermore in times of stress, technical problems such as settlement failures could even increase market stress. We aim in this paper at identifying weak points in the repo market and make some suggestions for its further improvement, focusing on the Korean repo market.

\section{Comparison between US and European Repo Markets}

\section{Definitions}

A repo is the sale of a security (or a portfolio of securities) combined with an agreement to repurchase the security (or portfolio) on a specified future date at a pre-arranged price. It is classified in accordance with the direction of the trade into two types - repos for the collateral (securities) providers (or sellers, borrowers), and reverse repos for the cash providers (or buyers, investors). By providing a security as collateral, a borrower can borrow money at a lower interest rate compared to the case of unsecured loans in which no collateral is provided. A buyer ${ }^{3}$ ) also can secure his lending by selling the collateral (security) in the case of the borrower's default.

\section{Types of repos}

Depending upon whether an intermediary between the borrower and the investor is involved, repos are classified into the two types - bilateral and tri-party repos. In a bilateral repo, the payment and securities delivery are executed simultaneously between the two parties through their own infrastructures, or through the use of services such as collateral management provided by their

3) Although buyers are allowed to sell the collateral (securities) to earn capital gains before the maturity date, they must fulfill the agreement by returning securities equivalent to that pledged as collateral on the maturity date. 
custodian banks:

Figure 1: Bilateral Repo Trades

<starting leg>

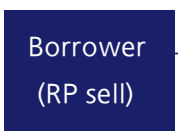

$<$ closing leg>

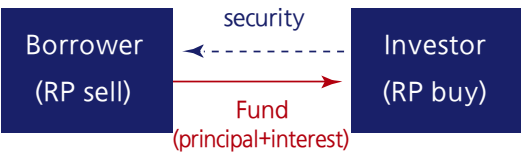

In a tri-party repo, the borrower and the investor use repo trade services provided by a third-party agent such as a CSD (central securities depository) or clearing bank. On behalf of the borrower and the investor, the third-party service provider performs settlement, custody and collateral management.4)

Figure 2: Tri-party Repo Trades

<starting leg>

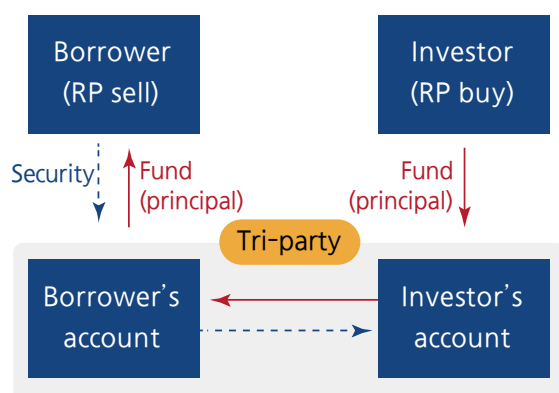

$\langle$ closing leg>

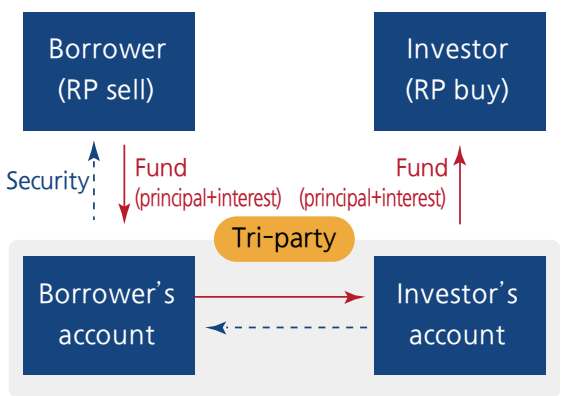

Depending upon the characteristics of the securities provided as collateral, a repo is distinguished as a GC (General Collateral) repo or an SC (Special Collateral) repo. In a GC repo, only the types of eligible securities that are agreed on between the two parties before trading are accepted as collateral. Borrowers use GC repos for financing (cash-driven) because of the ease of collateral allocation and replacement. Investors seeking short-term returns accept securities regardless of their

4) For example, collateral allocation, evaluation (marking to market), and replacement. 
types, as long as they meet a certain level of liquidity and safety as collateral.5)

In an SC repo, only a certain set of securities can be utilized as collateral and collateral replacement is prohibited until the day of maturity, so that buyers use SC repos to acquire certain types of securities. A seller who has marketable securities can borrow money at a lower interest rate than when borrowing through a GC repo.

\section{US and European Repo Markets}

\section{A. Size of Repo Markets}

The size of the repo markets in the US had grown at a fast pace thanks to the securities such as MBSs, ABSs, CMOs (Collateralized Mortgage Obligations) and CDOs (Collateralized Debt Obligations) starting to be accepted as collateral for repo trades from 2000. However, immediately after the collapse of Lehman Brothers, they shrank substantially and remained at low levels for an extended period. The outstanding repo value of primary dealers had grown to 4.6 trillion dollars before the collapse of Lehman Brothers, but after that, it reduced to a size of 2.2 trillion dollars as of September 2009. Currently it is recovering from the meltdown, though at a much lower speed.

In Europe, the outstanding repo value of financial institutions stood at 3.4 trillion euro in June 2007; however the market also shrank after the collapse of Lehman Brothers to register 2.3 trillion dollars at its lowest point. Toward the end of 2009, it showed a dramatic increase though, due to the ample provision of liquidity by the ECB in response to the sovereign debt crisis, but it has been shrinking again since 2011.

5) In the case of the US repo markets, treasury and agency securities whose maturities are less than 10 years serve as the primary collateral for GC repos. In special cases, treasury and agency securities of greater than 10-year maturity, MBSs (mortgage-backed securities) and corporate bonds can also be occasionally accepted as collateral. 
Figure 3: US and European Repo Market Sizes

(US)

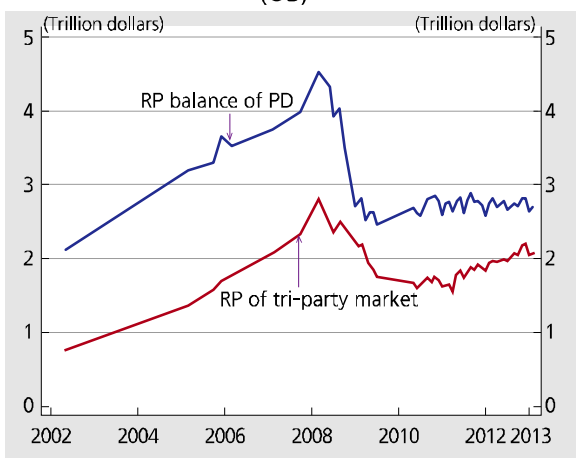

Note: Based on outstanding repo trades and on the value of collateral of Primary dealers and of Tri-party. repo market respectively.

Source: FRBNY.
(Europe)

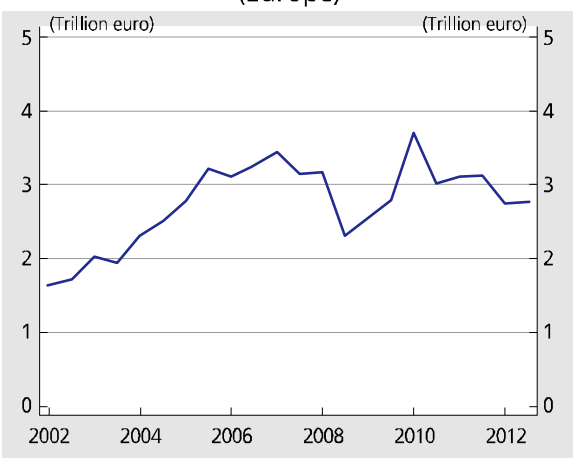

Note: Based on repo trades of about 64 financial companies.

Source: ICMA.

\section{B. Types of Markets and Participants}

While tri-party repos are prevalent in the US, bilateral repos account for most of the trading in Europe. Broker-dealers in the US, as major borrowers, use primarily tri-party repos for financing their securities inventories, and bilateral repos as supplements. The tri-party repo market accounts for from $65 \%$ to $80 \%$ of the overall US repo market.6) Although the bilateral repo market dominates in Europe, the share of the tri-party repo market has recently been increasing.7)

Primary dealers in the US, and banks and their affiliates in Europe, mainly act as sellers in the repo markets. Securities dealers hold securities for market-making, dealing and primary broker services, and finance by borrowing through repos and issuing commercial paper. For repo financing, they count on the tri-party repo market. In Europe, banks' share in total securities holdings of financial companies overall is relatively high compared to that of US banks, and they manage the bonds entrusted by asset management companies. Such favorable business environment

6) See FSB (2012).

7) The share of the tri-party repo market stood at $7.1 \%$ in 2009 , and expanded steadily from there to $8.6 \%$ in 2010 and to $12.6 \%$ in 2011 (ECB 2011). 
makes them to be able to utilize securities in repo financing.

In the aspect of fund investment, investors such as MMFs (money market funds), insurance companies and pension funds use repos for safe short-term investment in both the US and the European markets. In the US tri-party repo market, the major investors are MMFs (accounting for from $25 \%$ to $33 \%$ of the overall market) and securities lenders (accounting for 25\%) such as custodian banks, pension funds and insurance companies ${ }^{8)}$, and about 4,000 companies including firms and local governments ${ }^{9)}$ invest in it. In Europe, banks, MMFs and large insurance companies participate in the bilateral repo markets, and in the tri-party markets, central banks and international institutions participate as well.

\section{Infrastructure}

Like a regular buy-sell securities trade, a repo trade runs through several processes including (1) trade execution, (2) CCP clearing10), and (3) delivery and payment settlement of securities and funds:

Figure 4: Repo Trade Processing Flow ${ }^{1)}$

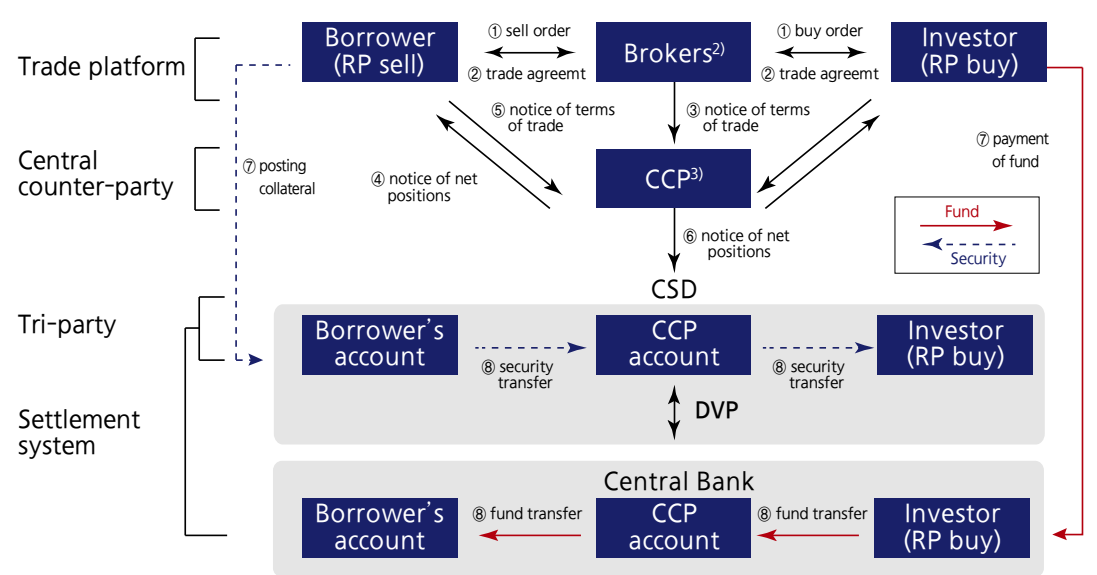

8) Securities lenders can make additional money by reinvesting the cash (collateral) earned from lending the securities that they hold.

9) See Copeland, Martin, and Walker (2010).

10) This is an optional feature in the repo markets and can be applied to both bilateral and tri-party repos. 
Notes: 1) Starting leg basis.

2) Direct trades can be carried out between trading parties without the involvement of brokers or electron-platforms.

3) CCP clearing may not be applied, depending upon the conditions under which the individual trades are conducted.

Source: Adaptation based on Nomura Research Institute (2010).

At the stage of trade capture, the investor (borrower) can make an offer to buy (sell) bilaterally, via phone or email. Trades can also be concluded through automated trading platforms or inter-dealer brokers. In the US most repo trades are agreed bilaterally by phone (or email), or through automated trade platforms (e.g. Tradeweb, BrokerTec), and the share of trading conducted through inter-dealer brokers is relatively low (FRBNY 2010). In Europe, direct agreement (50\%) is widely used, although trades through automated transaction systems (e.g. BrokerTec, Eurex, Repo MTS) $(30.0 \%)$ or inter-dealer brokers (20.3\%) have recently been on the rise. ${ }^{11)}$

CCPs (central counter-parties) reduce counter-party risks by taking over the trading parties' credits and obligations, and save settlement liquidity by using multilateral netting mechanisms. In the US, the FICG (Fixed Income Clearing Corporation) ${ }^{12)}$ provides CCP clearing services. In that about $15 \%$ of tri-party repos are cleared ${ }^{13)}$ and the level of usage of CCP clearing services is low.

In Europe, $60 \%$ of bilateral repos are cleared through CCPs ${ }^{14)}$, which indicates that the share of CCP cleared repos is higher than in the US, and LCH. Clearnet (U.K., France), Eurex Clearing (Germany) and CC\&G (Italy) provide CCP clearing services:

\footnotetext{
11) See ICMA (2012).

12) It is a subsidiary of the DTCC (Depository Trust \& Clearing Corporation) which provides services such as trade confirmation and clearing with treasury bonds, agency debentures, and MBSs.

13) See the website of Federal Reserve Bank of New York.

14) See ECB (2012).
} 
Figure 5: Bilateral Clearing and CCP Clearing
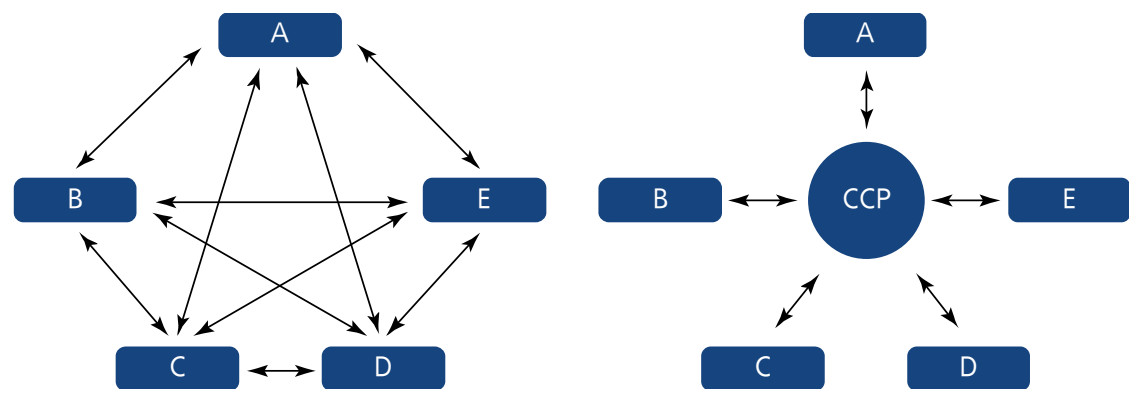

In tri-party repos, an agent conducts on behalf of counter-parties the securities and cash settlement, custody, and collateral management, and in some cases provides borrowers with intraday liquidity. In the US, as third-party service providers clearing banks such as JP Morgan Chase and the Bank of New York Mellon provide intraday credits to borrowers within the range of repo trade value during the period between the unwind and the rewind times.

In Europe, ICSDs ${ }^{15)}$ such as Euroclear Bank and Clearstream Banking Luxembourg serve as third-party intermediaries and provide intraday liquidity within limits to resolve time-lag problems in international trades.

Table 1: Types of Repos in US and Europe

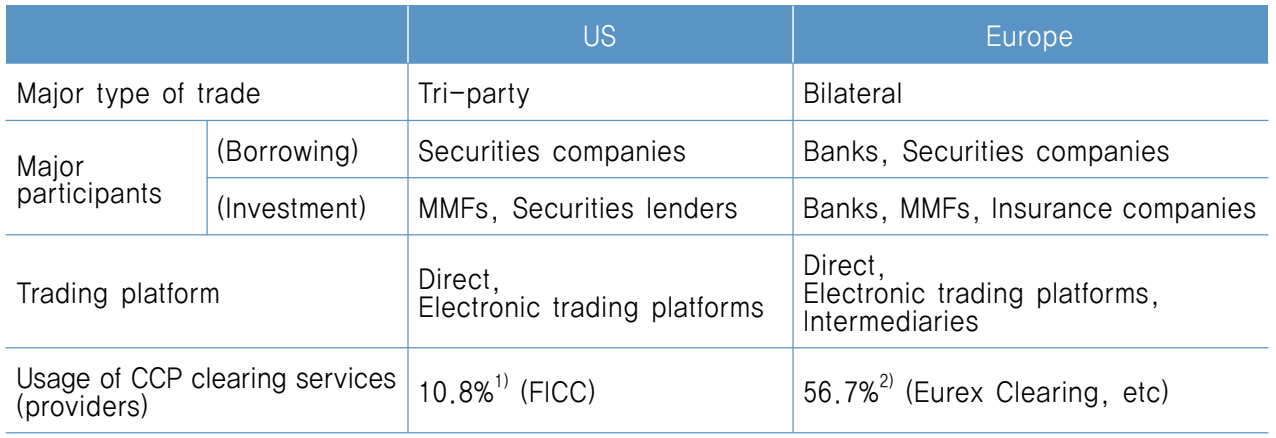

15) The ICSD (International Central Securities Depository) opens an omnibus account to enable investors to trade various countries' securities without their own accounts in each country. Euroclear Bank and Clearstream Banking Luxembourg provide settlement services in about 90 and 34 countries respectively. 


\begin{tabular}{l|l|l|l}
\multicolumn{2}{l|}{} & \multicolumn{1}{c|}{ US } & \multicolumn{1}{c}{ Europe } \\
\multicolumn{2}{l|}{ Third-party service providers } & Clearing banks & ICSDs \\
\hline $\begin{array}{l}\text { Payment } \\
\text { system }\end{array}$ & (Securities) & FRB, DTC, Clearing banks & Countries' CSDs, ICSDs \\
\hline
\end{tabular}

Notes: 1) As of December 2011 (FRBNY).

2) In 2011 (ECB).

At the stage of securities and cash settlement, the securities are delivered through book-entry transfers by the CSD and the cash payments are typically settled in the LVPSs (Large Value Payment Systems) operated by the central banks concerned.

Table 2: Payment Systems for Repos in US and Europe

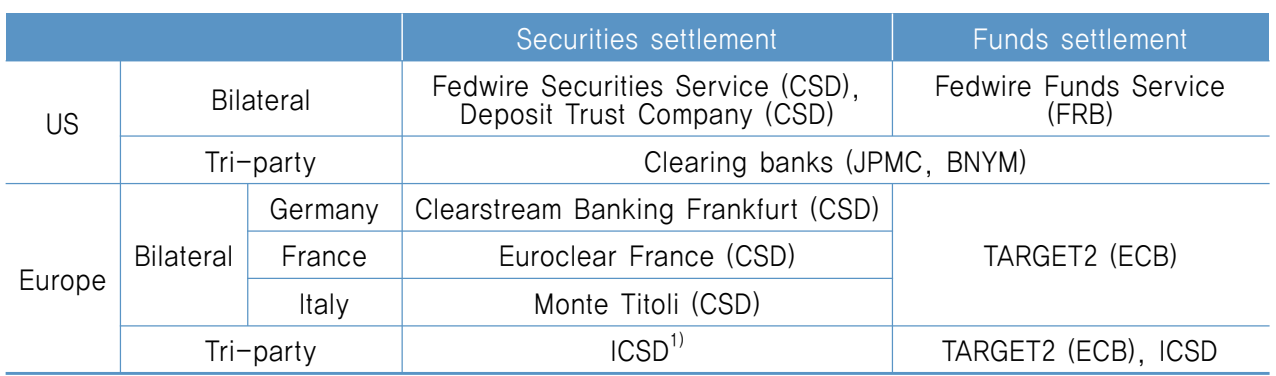

Note: 1) Clearstream Banking Luxembourg, Euroclear Bank.

Source: BIS (2010b).

\section{Experiences of the Global Financial Crisis ${ }^{16)}$}

\section{A. Development of the Crisis}

The impact of the global financial crisis differed in line with the characteristics of the US and European repo markets. In this section the developments in each market before and after the crisis will be discussed, using the movements of the spread between the rate for GC repos, whose collateral are mainly highly liquid

16) The analysis of this section is based on Hördahl and King (2008) 
government bonds, and the almost risk-free OIS rate. ${ }^{17)}$

\section{(Pre-crisis Period)}

Both the GC repo and the OIS rates had moved close to the central banks' policy rates due to their low credit risk during the pre-crisis period. The GC repo rate had been slightly lower than the OIS rate because of GC repos' larger market size and counter-party risk reducing collateral basis trading features compared with OIS. The GC repo rate, however, did rise above the OIS rate at critical times during the pre-crisis period although eligible collateral was pledged to reflect increased counterparty risk.

\section{Figure 6: GC Repo-OIS Spread}

(US)

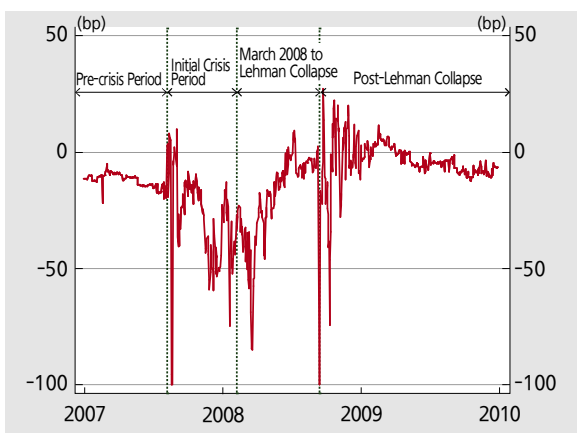

(Europe)

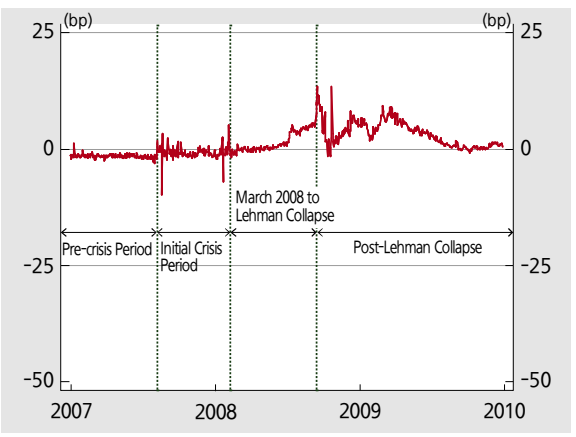

Note: 3-month term basis.

Sources: Bloomberg, European Banking Federation.

Until mid-2007, the GC repo rates were from about 5 to 10bp lower than the OIS rate in the US market, and from 1 to $2 \mathrm{bp}$ lower in the European market. In particular, US repos utilizing less liquid credit collateral such as MBSs had rates marginally higher, by about 1 to $2 \mathrm{bp}$, than the OIS rate.

17) An OIS (overnight index swap) is an interest rate swap in which a fixed rate is exchanged for a floating rate within a specified period. The Federal Funds rate (US) and the EONIA rate (Europe) are used as the underlying assets. The credit risk of an OIS is low because at maturity the trading parties settle their net exposures, but not the principal. Notably, the fixed rate exchanged for the floating rate is called the OIS rate, and reflects the expected average interest rate of its underlying asset. 


\section{(Initial Crisis Period: Mid-2007 to February 2008)}

In August 2007, BNP Paribas halted redemptions on its investment funds because of difficulties in valuing their holdings as the US credit markets no longer worked seamlessly. The unsecured inter-bank loan markets in the US and Europe also suffered from the drying-up of liquidity, and the repo markets found counter-party risks increasing. In response, securities dealers' pre-cautionary moves to secure liquidity in preparation for customers' increased redemption demand became more apparent.

Figure 7: Libor-OIS Spread and Euribor-OIS Spread
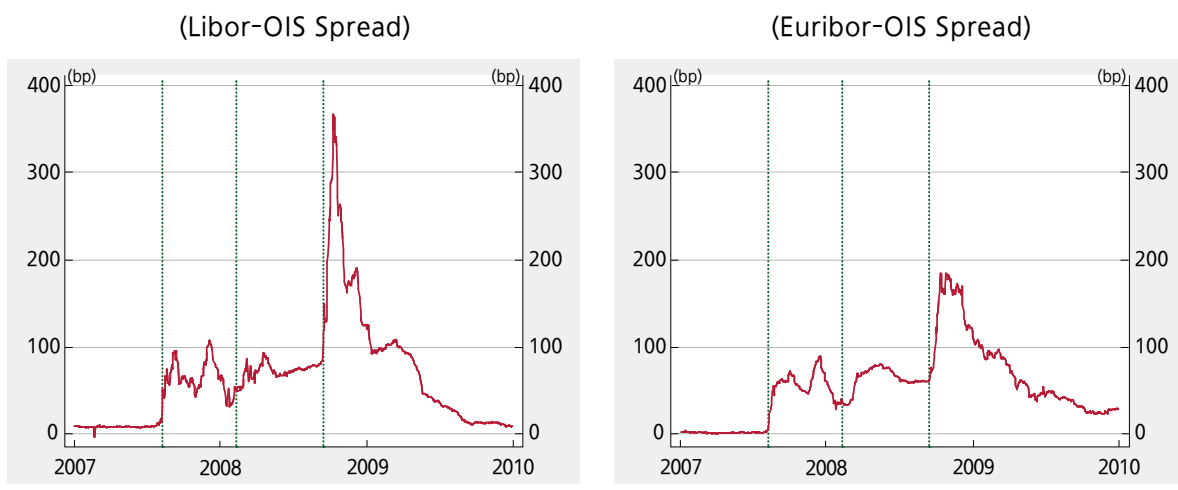

Note: 3-month term trade basis.

Sources: Federal Reserve Bank of St. Louis, European Banking Federation, Bloomberg.

A stronger preference for safe assets such as US Treasury bonds and an increase in repo rate volatility became more apparent in the US repo market. The US GC repo rate fell further below the OIS rate, and the spread thus widened from 5 to $10 \mathrm{bp}$ to $50 \mathrm{bp}$. The European market in contrast did not show any stress, with the spread remaining at its usual range until early 2008.

\section{(March $2008 \sim$ Lehman Brothers' Collapse)}

As the Bear Stearns liquidity crisis amplified the financial market instability, the repo market also saw its trading volume shrinking. Safe assets such as Treasury bonds were more strongly preferred as collateral, while corporate bonds and 
structured products were less desired. As a result, the spread between the GC repo and OIS rates expanded to 80bp. However, thanks to the Fed's efforts through its TSLF (Term Securities Lending Facility) for the provision of Treasury bonds, and its PDCF (Primary Dealer Credit Facility) for the supply of liquidity to primary dealers, the spread continued to narrow to return to its pre-crisis period level at 10bp in August 2008.

\section{Table 3: Fed's Liquidity Provision Facilities during Crisis}

\begin{tabular}{|c|c|c|}
\hline & $\begin{array}{c}\text { TSLF } \\
\text { (Term Securities Lending Facility) }\end{array}$ & $\begin{array}{c}\text { PDCF } \\
\text { (Primary Dealer Credit Facility) }\end{array}$ \\
\hline $\begin{array}{l}\text { Time of } \\
\text { introduction }\end{array}$ & - Mar. 2008 Feb. 2010 & - Mar. 2008 Feb. 2010 \\
\hline Target & - PDs (primary dealers) & - PDs (primary dealers) \\
\hline Aim & - Support for repo markets & - Provision of emergency liquidity \\
\hline Form & $\begin{array}{l}\text { - Bonds for bonds } \\
\text { (lending of government bonds) }\end{array}$ & $\begin{array}{l}\text { - Cash for bonds } \\
\text { (emergency liquidity assistance) }\end{array}$ \\
\hline Collateral & $\begin{array}{l}\text { - Securities eligible for open } \\
\text { market operations } \\
\text { - AAA-rated MBSs issued by } \\
\text { private financial institutions }\end{array}$ & $\begin{array}{l}\text { - Securities eligible for open market } \\
\text { operations } \\
\text { - Securities pledged in tri-party repo market } \\
\text { (BBB-rated corporate bonds, MBSs, ABSs, } \\
\text { etc.) }\end{array}$ \\
\hline Initial amount & - $\$ 200$ billion & - Unlimited \\
\hline Term & - 28 days & - 1 day \\
\hline Interest rates & - Auction rates & - Rediscount rates \\
\hline
\end{tabular}

Note: 1) Government bonds, agency debentures, agency MBSs.

Source: Federal Reserve Bank of New York.

In Europe, as counter-party risk was steadily rising and the secured money markets were also coming under stress following the unsecured loan markets, the GC repo rate started to remain fixed at a level some 5bp higher than the OIS rate as banks' dependence on the repo markets for financing grew due to the dysfunctional unsecured loan markets. Unlike the Fed, however, until the time of Lehman Brothers' collapse the ECB did not introduce any unconventional monetary policies to provide liquidity to the financial markets.

\section{(Post-Lehman Brothers' collapse)}

Immediately after Lehman Brothers filed for bankruptcy, market interest rates 
moved by large margins - indicative of the markets becoming more unstable. Especially in the US, the spread widened to a range of plus 20 to negative $80 \mathrm{bp}$, due to the growing preference for safe assets and the Fed's policy responses. Europe also saw its repo market activity declining with the spread widening to 10bp.

After the second quarter of 2009, however, the GC repo rate remained below the OIS rate by about 5 to 10bp in the US, and both rates became more or less equal in Europe as the efforts of the Fed and the ECB bore fruit.

\section{Table 4: Fed's and ECB's Reponses to Lehman Brothers' Collapse}

\begin{tabular}{|c|c|}
\hline Fed & ECB \\
\hline $\begin{array}{l}\text { - Support for credit markets } \\
\text { - Introduction of AMLF, CP and CPFF to } \\
\text { support ABCP market (Sep. and Oct. 2008) } \\
\text { - Purchase of government-guaranteed } \\
\text { institution bonds to support MBS market } \\
\text { (Nov. 2008) } \\
\text { - Purchase of government bonds and MBSs } \\
\text { - Direct purchase of US government bonds and } \\
\text { MBSs through three quantitative easing programs } \\
\text { (Mar. 2009) }\end{array}$ & $\begin{array}{l}\text { - Provision of liquidity to financial institutions } \\
\text { - Enlargement of set of eligible securities } \\
\text { rating (including bank bonds) and lowering of } \\
\text { eligible credit (Oct. 2008) } \\
\text { - Support for credit markets } \\
\text { - Support for mortgage-backed covered bond } \\
\text { market (May 2009) } \\
\text { - Purchase of government bonds } \\
\text { - Purchase of government bonds of bailed out } \\
\text { countries (e.g. Greece, Ireland) (May 2010) }\end{array}$ \\
\hline
\end{tabular}

\section{B. Comparison of US and European Markets}

During the global financial crisis the repo markets in the US and Europe showed differing movement over the course of its evolution. The US repo market showed relatively higher volatility compared to that of Europe, and the speed of recovery in the aftermath of the crisis was more protracted. Unlike in the US, the GC repo-OIS spread in Europe was little affected during the early period of the crisis, and it also moved in a direction opposite to that in the US as the crisis deepened. The US spread moved more in accordance with changes in government bond supply and demand conditions18), but the spread in Europe changed in reflection of the overall situation related to liquidity supply and demand.

These differences between the US and Europe are attributable to the 
differences between them in how the crisis developed, in the roles of their government bonds as safe havens, and in the policy responses of their central banks. The US repo market, whose major participants are securities dealers, was sensitive to crisis symptoms and shrank continuously after the crisis hit. The European repo market however showed a relatively faster recovery from the shock of the crisis, since financially sound banks made up most of the major participants.

Figure 8: Shock amplification mechanism in repo markets

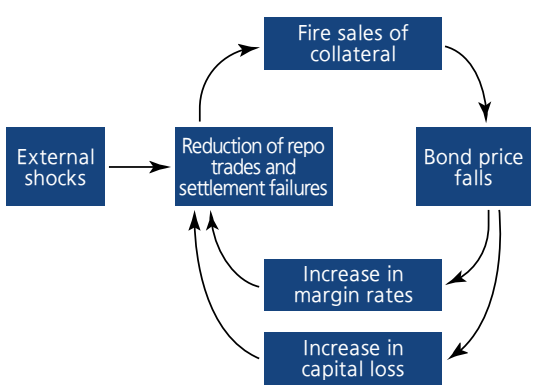

Table 5: Repo Rate Volatility ${ }^{1)}$

\begin{tabular}{l|c|c} 
& US & Europe \\
\hline Pre-crisis period & 2.86 & 0.47 \\
\hline Initial crisis period & 21.99 & 1.55 \\
\hline $\begin{array}{l}\text { March 2008 to } \\
\text { Lehman Collapse }\end{array}$ & 18.45 & 2.13 \\
\hline Post-Lehman Collapse & 12.82 & 2.81 \\
\hline \multicolumn{3}{|c}{ sote: 1) Standard deviation of GC RP-OIS } \\
spread. \\
Sources: Bloomberg, European Banking Federation.
\end{tabular}

Source: Brunnermeier (2009).

In the US, major investment institutions such as MMFs accepted only a limited range of collateral in response to the increased counter-party risks, and securities dealers' borrowing capacity also contracted due to the soaring scale of haircuts. ${ }^{19)}$ In Europe on the other hand, banks and other major market participants maintained financial soundness and actively used secured loans instead of unsecured loans, and in consequence, the impact of the financial crisis shocks persisted for only a short time.

Unlike in the US, where financial companies faced increased pressure to secure government bonds while the supply of government bonds to the market by foreign central banks and pension funds, who held great amounts of US government

19) With the increases in haircuts to $50 \%$ on ABSs and to $100 \%$ on structured bonds after the crisis, a large number of hedge funds failed because they could not respond to additional margin call requests. 
bonds, declined due to concerns about counter-party risks such as settlement failures20), In Europe, there was no significant increase in the demand for government bonds during the crisis, since along with government bonds corporate bonds were also accepted as ECB-eligible collateral.

On the other hand, the ECB already accepted a wider range of eligible collateral for open market operations than the Fed, and for this reason banks' reliance on government bonds was relatively low.

Figure 9: Treasury Delivery Failure

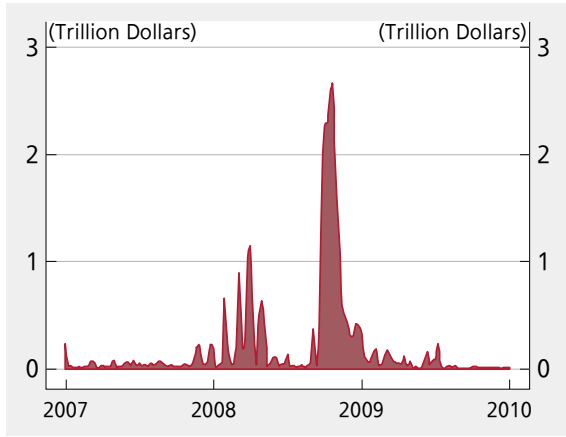

Source: Federal Reserve Bank of New York.
Table 6: Eligible Collateral for OMOs during Pre-Crisis Period

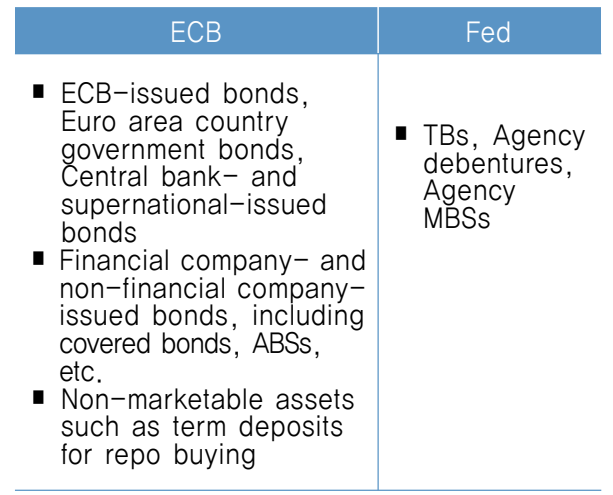

Sources: ECB, Federal Reserve Bank of New York.

\section{Conditions of Korean Repo Market, and Concerns}

\section{Conditions of Korean Repo Market}

Institutional repo trades ${ }^{21)}$ in Korea are processed by a DvP (delivery versus

20) During the two-year period before the global financial crisis, the average weekly amount of treasury delivery failure was about 90 billion dollars, but in the periods following the Bear Stearns liquidity crisis and Lehman Brothers' collapse, it soared to 1 trillion and to 2.7 trillion dollars respectively.

21) Institutional repos are divided into exchange-traded and OTC repos. Exchange-traded repos are 
payment) system that uses both the funds transfer system of the Bank of Korea (BOK) for funds transfer, and the book-entry transfer system of the Korea Securities Depository (KSD) for securities delivery. The KSD functions as a third- party agent, providing services such as daily marking-to-market and collateral substitutions. CCP clearing services have not yet been provided by any other companies in Korea.

Figure 10: Trade Processing Flow of Korean Repo Trades

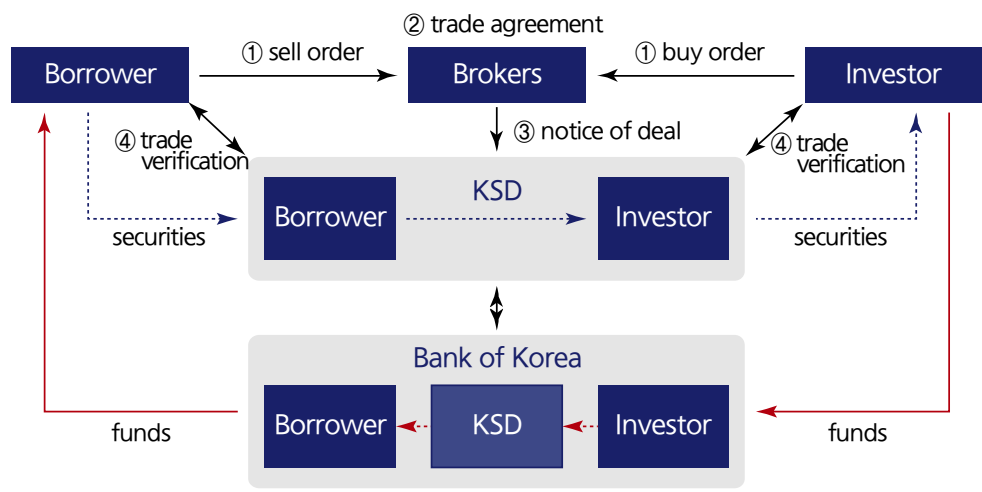

Note: Starting leg.

Source: Chang-yong Kwak and Sung-guan Yun (2013).

As of May 2013 the volume registered 20.5 trillion won, 11.4 times its level in 2008. Such rapid growth is ascribable to the expansion of the collateral pool to consist of not only government bonds but also corporate bonds, and to the short-term financial market reforms undertaken whereby a maximum cap on call borrowings was imposed on securities companies. ${ }^{22)}$

intermediated through an auction mechanism and cleared by the Korea Exchange (KRX) as the CCP for commercial banks and securities companies. Although the collaterals and maturities are standardized, the trading volume amounts to only 5\% of OTC-traded repos as of March 2013 (this paper therefore focuses hereafter mainly on the OTC-traded repo market).

22) In June 2011 the BOK, the Ministry of Strategy and Finance, and the Financial Services Commission agreed to gradually limit the amount of call money borrowing by securities companies, in a measure to minimize the possible emergence of systemic risk. 
Figure 11: Volume of Repo and Call Trades

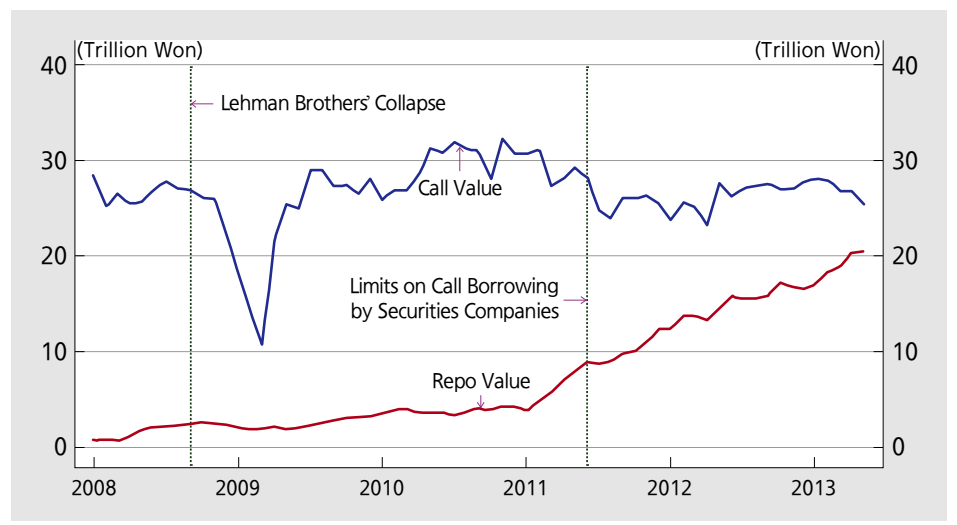

Note: Contracts basis.

Sources: BOK, KSD.

In the wake of the global financial crisis, along with asset management companies' heightened preference for secured loan lending with its lower settlement risks, the market grew rapidly as the symptoms of a financial crisis became more evident. Although the market was somewhat disturbed immediately after Lehman Brothers' collapse, with the repo rate rising to a great extent due to the heightened counter-party risk, it then recovered rapidly with the help of the proactive stabilization measures taken by the BOK.

The major repo borrowers in Korea are securities companies and securities trusts, while the major repo investors are asset management companies and securities trusts:

\footnotetext{
Limits on Securities Company Call Borrowing ${ }^{1)}$

\begin{tabular}{|c|c|c|c|c|c|c|}
\hline & June 2011 & July Sept. & Oct. $\sim$ Dec. & $\begin{array}{l}\text { Jan. } 2012 \\
\sim \text { March }\end{array}$ & Apr. June & July \\
\hline Schedule & $\begin{array}{c}90 \% \text { of excess } \\
\text { amount })^{2}\end{array}$ & $80 \%$ & $60 \%$ & $40 \%$ & $20 \%$ & $0 \%$ \\
\hline
\end{tabular}

Notes: 1) Maximum amount of borrowing limited to up to 25 percent of the borrowing company's equity size from July 2012; until that time, from June 2011 the amount of additional borrowing allowed beyond the $25 \%$ limit was gradually reduced.

2) The "excess amount" is the amount of loans in excess of the 25 percent of the borrowing company's equity size.
} 
Figure 12: RP Rate-Base Rate ${ }^{4)}$ and Trade Volume
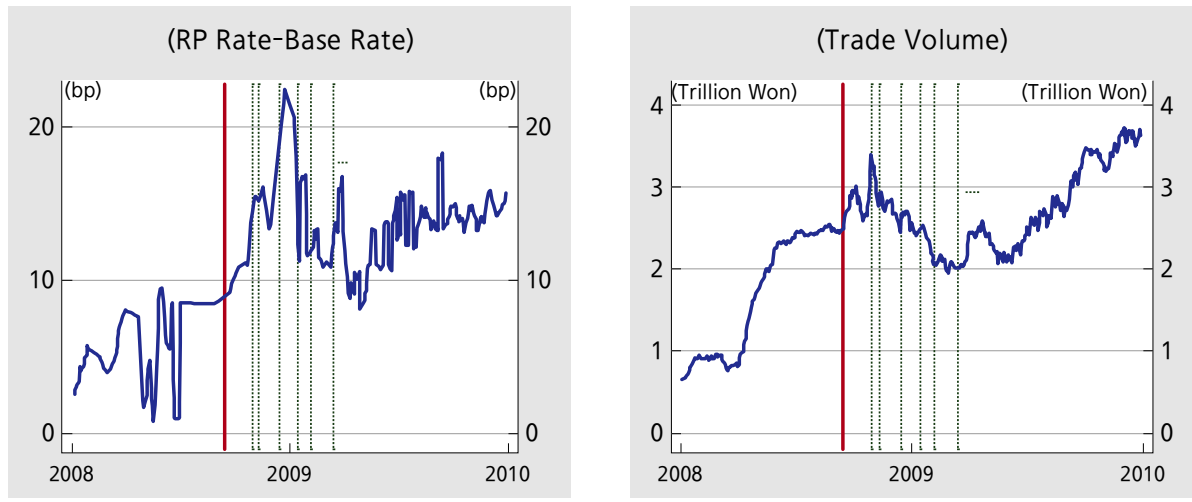

Notes: 1) The solid red lines indicate the day of the Lehman Brothers' collapse (September $15,2008)$.

2) The dotted green lines indicate the days of BOK reverse RP trading.

3) Based on trades (5-day moving averages).

4) Based on trades with liquid collateral, exclusive of provincial government bonds, corporate bonds, ETFs, and stocks.

\section{Table 7: Composition of RP Market Participants ${ }^{1)}$}

\begin{tabular}{c|r|l|r|r}
\multicolumn{2}{|c|}{ Borrowing } & \multicolumn{1}{|c}{ Financial Sector } & \multicolumn{2}{c}{ Investment } \\
\hline 3.2 & $(11.9)$ & - Banks & 2.5 & $(9.5)$ \\
\hline- & $(-)$ & - Bank Trusts & 2.0 & $(7.4)$ \\
\hline 1.3 & $(4.9)$ & - Foreign Bank Branches & 1.2 & $(4.5)$ \\
\hline 9.7 & $(36.7)$ & - Securities Co. & 0.9 & $(3.2)$ \\
\hline 6.4 & $(24.2)$ & - Securities Co. Trusts & 6.4 & $(24.1)$ \\
\hline 1.4 & $(5.4)$ & - Asset Mgt. & 7.3 & $(27.7)$ \\
\hline 3.7 & $(14.1)$ & - KSFC & 1.9 & $(7.2)$ \\
\hline 0.8 & $(2.8)$ & - Non-residents & 4.3 & $(16.4)$ \\
\hline 26.5 & $(100.0)$ & & 26.5 & $(100.0)$ \\
\hline
\end{tabular}

Notes: 1) Average daily balance basis, as of May 2013.

2) KSFC (Korean Securities Finance Corporation), insurance companies, and merchant banks. Source: KSD.

The share in total repo borrowings of securities companies has increased, due to the call money borrowing cap on them and to their need for diversification of financing channels. The share of securities trusts has also grown, thanks to the 
increase in securities entrusted them by customers since 2011.23)

Asset management companies, which invest short-term funds through call lending and reverse repos, still hold the first rank in terms of reverse repo amount, although their share has declined in line with the active participation of securities trusts:

Figure 13: Composition of RP Market Participants by Year
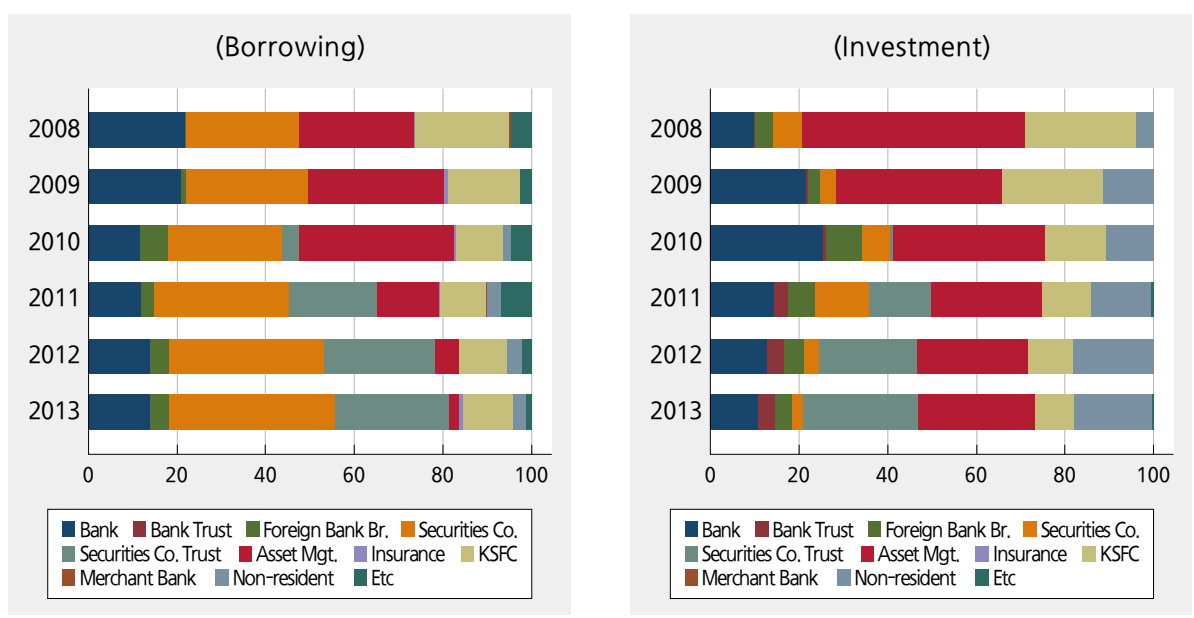

Note: Average daily balance basis, as of May 2013.

Sources: KSD, BOK.

23) In the revision of the Trust Business Act in July 2005, securities companies were permitted to operate trust businesses as ancillary operations, and in recent years, securities trusts have participated actively in the repo market to finance credit securities investment such as CP through repos using the securities entrusted to them. 


\section{$<$ Box 1>}

\section{Effects of Market Stabilization Measures during the Global Financial Crisis}

To stabilize the domestic financial markets during the crisis, the BOK expanded the set of securities and institutions eligible for BOK repo transactions. The analysis below is to test the policy impact on the repo market trades.

The effect on the spread (repo rate minus BOK Base Rate) of expanding the set of eligible securities was estimated using pooled OLS (Ordinary Least Squares) regressions with trade data from January 2, 2008 to November 6, 2009. The independent variable, Policy, indicates whether the additionally accepted securities are included in repo deals in Models 1 and 2, and the share of their size in the total repo in Models 3 and 4 respectively:

$$
\text { Rate }_{i, j}-\overline{\text { Policyrate }_{t}}=c+\gamma \text { Policy }_{t}+\beta X_{t}+\text { day }_{t}+\delta_{t}+\eta_{j}+\epsilon_{t}
$$

Rate $_{i, j}$ : repo rate, $\overline{\text { Policyrate }_{t}}$ : base rate, $X$ : size of the repo market, number of participants, etc, $\delta_{i}$ : borrower fixed effects, $\eta_{j}$ : investor fixed effects, day $y_{t}$ : time fixed effects

The results of estimation show that, before the expansion of the set of eligible securities, the repo rates for highly liquid securities such as government bonds differed significantly from (were lower than) the repo rates for bank debentures or special bonds. These differences were however not statistically significant after the policy was introduced. The policy contributed to alleviating credit crunches in the repo market, by enhancing the eligibility of bank debentures and special bonds as collateral for repo trades:

\section{Estimation Results}

\begin{tabular}{l|c|c|c|c} 
& $(1)$ & $(2)$ & $(3)$ & $(4)$ \\
\cline { 2 - 5 } Policy & Pre-policy & Post-policy & Pre-policy & Post-policy \\
& $0.186^{* *}$ & -0.224 & $0.002^{* *}$ & -0.002 \\
& $(0.086)$ & $(0.708)$ & $(0.001)$ & $(0.007)$ \\
\hline Num. of obs. & 23,517 & 48,024 & 23,517 & 48,024 \\
\hline $\mathrm{R}^{2}$ & 0.84 & 0.56 & 0.84 & 0.56 \\
\hline
\end{tabular}

Notes: 1) Overnight repo trades with BOK repo eligible collateral.

2) Excluding last days of reserve maintenance periods.

$3) * * *, * *$ and $*$ indicate significance levels of $1 \%, 5 \%$ and $10 \%$ respectively, while the figures in ( ) are standard-errors. 


\section{Concerns to be addressed}

\section{A. Increase of Trade Concentration}

In the US, as repos are traded mainly by securities dealers (borrowing) and MMFs (investment), and a few institutions account for a large proportion of the trades, the trade concentration is very high. The top five and the top ten institutions ranked in terms of borrowing size accounted for $57 \%$ and $88 \%$ respectively of the total trading as of end-2010, and the share of the top ten institutions ranked in terms of lending size amounted to about $60 \% .24)$ Notably, some securities dealers finance about 70 percent of their total borrowings through the repo markets.

Table 8: Leverage and Repo Shares of Major US Securities Dealers

\begin{tabular}{l|c|c|c|c|c} 
& $\begin{array}{c}\text { Goldman } \\
\text { Sachs }\end{array}$ & $\begin{array}{c}\text { Merrill } \\
\text { Lynch }\end{array}$ & $\begin{array}{c}\text { Morgan } \\
\text { Stanley }\end{array}$ & JP Morgan & average \\
\hline Leverage (times) & 11.8 & 11.4 & 37.4 & 34.3 & 23.7 \\
\hline $\begin{array}{l}\text { Repo financing over } \\
\text { total borrowings (\%) }\end{array}$ & 26.5 & 42.8 & 65.8 & 74.3 & 52.4 \\
\hline
\end{tabular}

Note: As of end-2010.

Source: Bankscope.

Although the level of concentration in the Korean repo market is not high, trades are coming to be concentrated among a few borrowing institutions such as securities companies. The share accounted for by the top ten borrowing institutions increased from $48 \%$ in 2008 to about $53 \%$ in 2012.

24) Some securities dealers in the US carried out over $70 \%$ of their total borrowings through the repo markets. 
Figure 14: Repo Concentration, by Major Participants ${ }^{1 / 2)}$

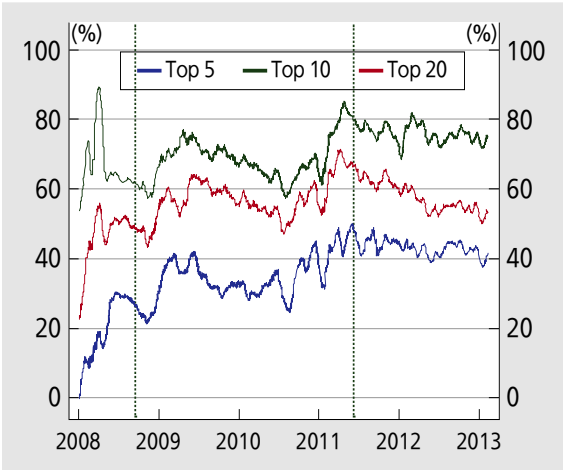

Table 9: Comparison of Repo Concentrations by Country

(\%)

\begin{tabular}{l|c|c|c|c}
\multirow{2}{*}{ - Top 5 } & 41 & 38 & 57 & - \\
\cline { 2 - 4 } & $\mathrm{RP}^{1 / 3)}$ & Call $^{1 / 3)}$ & US $^{3)}$ & Europe \\
- Top 10 & 53 & 55 & 88 & 61 \\
\hline - Top 20 & 75 & 74 & - & 82 \\
\hline
\end{tabular}

Notes: 1) Top borrowers in the call and RP markets, based on trades in 2012.

2) 20-day moving averages, exclusive of the last days of the reserve maintenance periods.

3) Based on RP trades as of Jan. 2013 for Korea and from July 2009 to Jan. 2010 in the tri-party market for the US, and on RP and Reverse RPs in Dec. 2009 for Europe.

Sources: BOK, KSD, ICMA (2013), Copeland et al. (2010).

A financial institution can increase its leverage through repeated repos 25 ), but by doing so it can also worsen its financial soundness when it is forced into a fire-sell of its assets in response to mounting losses of asset value, margin call requests, and stronger fund redemption demand initiated by increased financial market instability. The more trades there are concentrated among a small number of financial institutions, the more the settlement risks of those institutions are likely to develop into systemic risk.

\section{B. Increase in the Share of Low Liquid Security Collateral}

During the global financial crisis, the shares of low liquid security collateral ${ }^{26)}$ in the US and Europe repo markets fell significantly. The volume of repos conducted

25) When a firm purchases one billion dollars' worth of securities with its own capital, and borrows money with these purchased securities through repos, and then does the same trades again, assuming that the haircut is $5 \%$ it can increase its investment to a maximum of 20 billion dollars.

26) Low liquid securities are classified by whether they are accepted for central banks' open market operations. In this paper government bonds, government agency debentures and covered bonds in the EU, and Fed non-eligible securities in the US are defined as low liquid securities. 
with Fed non-eligible securities in the US tri-party market plunged from 600 billion dollars in July 2008 to around 250 billion dollars in July 2009. In Europe, the share of repos using non-sovereign bond securities dropped to about $50 \%$ from the middle of 2009 , from $70 \%$ to $80 \%$ of total tri-party repos before the financial crisis (Copeland, Martin, and Walker, 2010). However, the shares did not decline as low as was considered desirable in either market, and still registered $40.2 \%$ in Europe and $18.3 \%$ in the US in 2011.

Figure 15: Types of Collateral and Concentrations
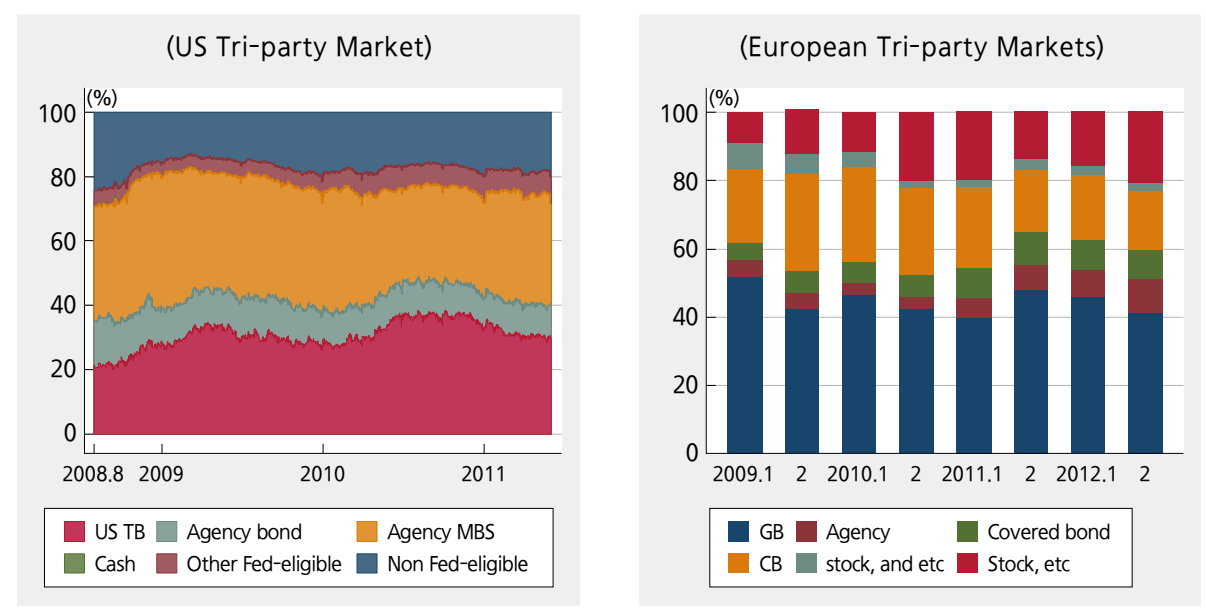

Sources: FSOC (2011), ICMA (2013).

As of May 2013, the share of low liquid securities (exclusive of government bonds, Monetary Stabilization Bonds, and special bonds) in the Korean repo market stood at $26.5 \%$ - lower than that in Europe, but higher than in the US. Although the share of bank bonds has shown a continued decline ${ }^{27)}$, the share of low liquid securities including other financial bonds has increased significantly, from $4.5 \%$ in January 2011 to $16 \%$ in January 2013.

27) Bank bonds have been continuously redeemed due to the loan-to-deposit ratio regulation and to the movement toward deleveraging since the global financial crisis from Q1 2009. 
Table 10: Values and Concentrations by Type of Collateral ${ }^{1)}$

(trillion won, \%)

\begin{tabular}{l|r|r|r|r}
\hline & Jan. 2011 & \multicolumn{2}{|c}{ May 2013} \\
\hline - TBs & 5.8 & $(43.9)$ & 11.6 & $(44.5)$ \\
\hline $\begin{array}{l}\text { Stabilization Bonds } \\
\text { - Special bonds }\end{array}$ & 3.2 & $(24.0)$ & 2.1 & $(8.1)$ \\
\hline - Bank bonds & 2.0 & $(12.7)$ & 5.4 & $(20.9)$ \\
\hline $\begin{array}{l}\text { - Other financial } \\
\text { debentures }\end{array}$ & 0.1 & $(0.7)$ & 1.7 & $(6.5)$ \\
\hline - CBs, etc. ${ }^{2)}$ & 0.5 & $(3.7)$ & 2.5 & $(10.5)$ \\
\hline Total & 13.3 & $(100)$ & 26.0 & $(100)$ \\
\hline
\end{tabular}

Notes: 1) Market value and end-of-month basis. 2) CBs, ETFs, stocks, provincial bonds. Source: KSD.
Figure 16: Concentration of Low Liquid Collateral

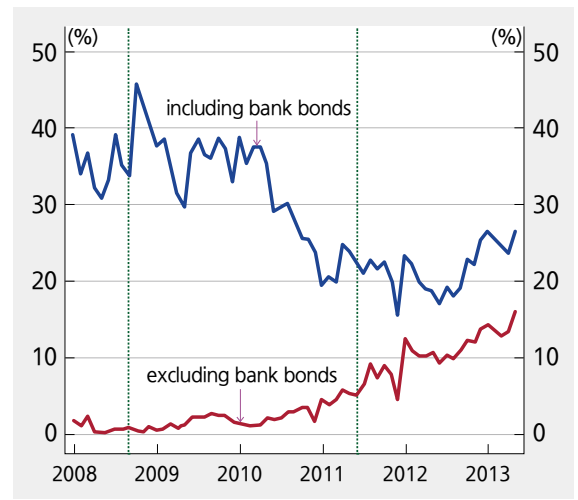

Note: Other financial debentures, CBs, ETFs, stocks, provincial bonds, bank bonds. Source: KSD.

The size of the exposure to low liquid securities (exclusive of bank bonds) of the top five investors is tantamount to only $16.4 \%$ of their total repos on average, but some investors have high shares of above $50 \%$. In particular, securities trust companies have increased the proportion of their repos carried out with low liquid securities, to search for additional yield with the mutual agreement of their settlors. Low liquid securities tend to increase the volatility of securities prices and to accelerate financial institutions' deleveraging because their sales take considerable amounts of time. ${ }^{28)}$

28) Begalle et al. (2013) estimated that, to sell a 200 billion-dollar portfolio while not causing any large change in bond market prices, the time required is nine days for government bonds but 30 days for ABSs. 
Figure 17: Illiquid Collateral Concentrations ${ }^{1)}$ of Top Five Ranked Investors

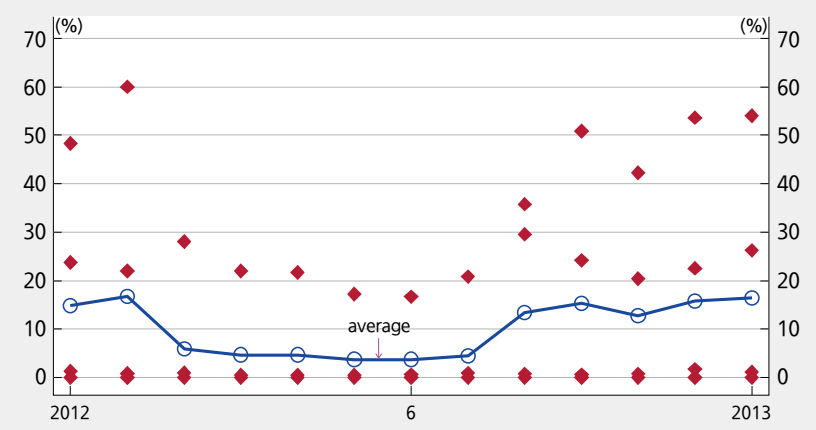

Note: 1) low-liquid securities (exclusive of bank bonds) based repos to total repos.

Sources: KSD, BOK.

\section{Rigidity of Margin Rate Variability}

Repo market participants in the US and Europe have flexibly adjusted the haircuts (or initial margins) based on counter-party credit risks and changes in the market prices of collateral. As of December 2012 haircuts in the US tri-party market were $2 \%$ for US Treasury bonds, $3 \%$ for corporate bonds and $5 \%$ for stocks, and in the European tri-party markets they were $2.7 \%$ for government bonds, $5.5 \%$ for corporate bonds and $8.7 \%$ for MBSs.

Figure 18: Haircuts
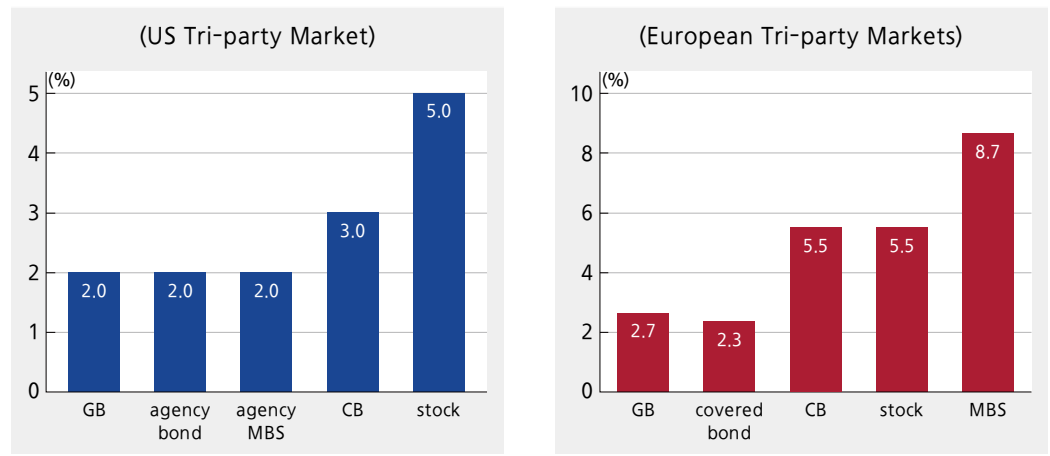

Note: As of December 2012.

Sources: Federal Reserve Bank of New York, ICMA (2013). 
In the Korean repo market, the margin rate ${ }^{29)}$ is currently at around $105 \%$ on average, irrespective of the types of securities pledged as collateral.

Figure 19: Margin Rates For Liquid Figure 20: Composition of Margin Rates and Illiquid Collateral-Based Trades

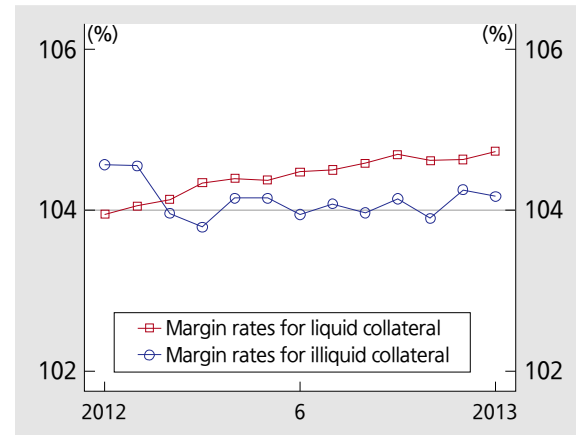

Notes: 1) Monthly averages

2) Excluding trades based on bank bond collateral.

Sources: BOK.

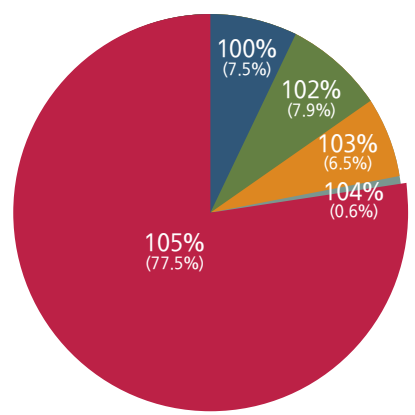

Notes: 1) From Jan. 2012 to Jan. 2013.

2) Excluding trades based on bank bond collateral.

3) Figures in ( ) indicate the percentages shares.

Sources: BOK, KSD.

In a situation in which the margin rate is not flexibly adjusted in accordance with the type of securities involved, when the financial markets become unstable, investors may try to avoid repo trades in which low liquid securities are offered as collateral as much as possible, and as a consequence the roll-over risks of the given contracts may increase.

Table 11: Comparison of Collateral Pledging Practices (example)

\begin{tabular}{c|c|c|c|c|c} 
& \multicolumn{2}{|c|}{ Assumptions } & \multicolumn{3}{c}{ Collateral, and its size } \\
\cline { 2 - 6 } & value of trade & $\begin{array}{c}\text { haircut } \\
\text { (margin rate) }\end{array}$ & $\begin{array}{c}\text { Case 1: } \\
\text { GB only }\end{array}$ & $\begin{array}{c}\text { Case 2: } \\
\text { CB only }\end{array}$ & $\begin{array}{c}\text { Case 3: } \\
\text { GB and CB }\end{array}$ \\
\hline US & 100 & $\begin{array}{c}\text { GB: } 102 \% \\
\text { CB: } 110 \%\end{array}$ & GB 102 & CB 110 & $\begin{array}{c}\text { GB 51 } \\
\text { CB 55 }\end{array}$ \\
\hline Korea & 100 & $\begin{array}{c}\text { GB: } 105 \% \\
\text { CB: } 105 \%\end{array}$ & GB 105 & CB 105 & $\begin{array}{c}\text { GB 52.5 } \\
\text { CB 52.5 }\end{array}$ \\
\hline
\end{tabular}

Note: $\mathrm{GB}$ and $\mathrm{CB}$ indicate government and corporate bonds, respectively.

29) A haircut (margin rate) is used to hedge the risk of price volatility of a security pledged as collateral. The haircut refers to a percentage discount on the value of the collateral, and the initial margin is a percentage premium added to the market value of the security. 


\section{Increase in Settlement Risk}

Most of the repos in the US and Europe are overnight. The shares of overnight repos $^{30)}$ were estimated at $73 \%$ and $75.5 \%$ for the European bilateral and tri-party markets respectively during 2009, and at around $80 \%$ for the US tri-party market ${ }^{31}$ ) (Copeland et al., 2012).

\section{Figure 21: European Repo Market Maturity Distributions}
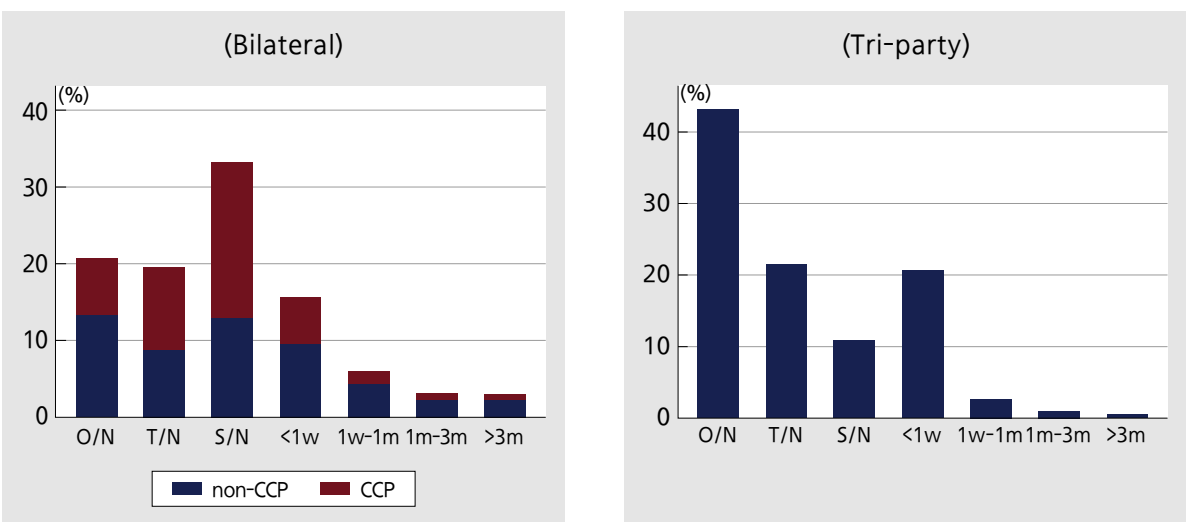

Note: Year 2009 basis.

Source: ECB (2009).

In Korea, as the share of overnight repos is large and the volume has continued to increase, the time of repo settlement has become gradually later. In 2012 overnight and open trades accounted for around $92.2 \%$ of total repos. ${ }^{32)}$ The average time of settlement, at 4:48 p.m., is approaching the BOK-Wire+ closing

30) In the calculation of the share of overnight repos, overnight consists of $\mathrm{O} / \mathrm{N}$ (overnight, from the trading day to the next business day), $\mathrm{T} / \mathrm{N}$ (tomorrow next, from the day following the trading day to the next), and $\mathrm{S} / \mathrm{N}$ (spot next, the next day after the date of the spot).

31) In the Fitch Ratings Fund \& Asset Manager Rating Group, the share of overnight repos in its MMF funds accounted for $81.8 \%$ of all repos (as of 31st August 2010).

32)

\begin{tabular}{l|c|c|c|c|c} 
& Overnight & Open & $2 \sim 7$ days & $8 \sim 14$ days & Etc. \\
\hline Percentage & $83.5 \%$ & $8.7 \%$ & $6.7 \%$ & $0.7 \%$ & $0.3 \%$ \\
\hline
\end{tabular}

Note: Based on trades conducted in 2012.

Source: KSD. 
time of 5:30 p.m. while the share of FOP (Free of Payment) has continuously declined.

Figure 22: FOP

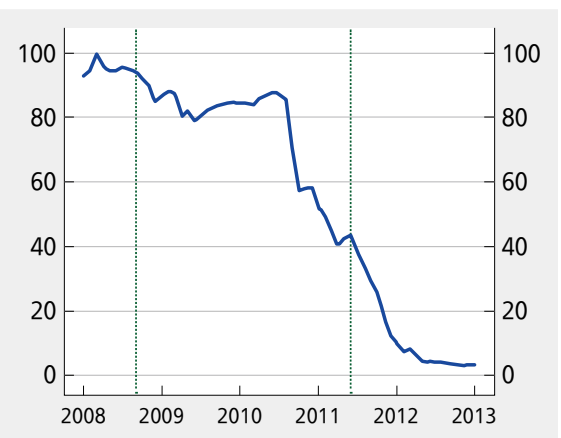

Notes: 1) Volume basis.

2) Excluding trades made during the last days of the required reserve maintenance periods.

Sources: BOK, KSD.

\section{Figure 23: Average Time of Settlement}

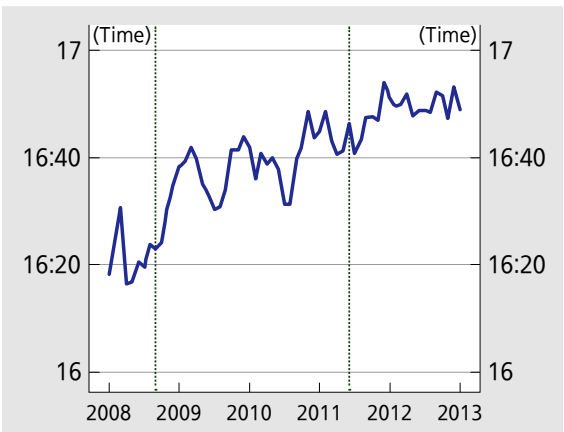

Notes: 1) Excluding trades made during the last days of the reserve maintenance periods.

2) Value-weighted average.

Sources: BOK, KSD.

In general, when an overnight repo is rolled over it entails more settlement processes ${ }^{33)}$ than a term repo. Along with such operational burdens for overnight repos, when a liquidity risk to a settlement system participant or a network failure occurs operational risks may increase. Furthermore, the increase in the number of settlements carried out at around the closing time may heighten the level of settlement risk. Investors such as securities companies usually settle their repos during the period from 4 to 6 p.m., in consideration of the benefits that may accrue through the reduction of settlement liquidity by delaying settlement, and the inter-connectedness with the time of settlement of OTC bonds.

33) For example, if a three-day maturity repo trade is settled. a settlement for each starting and closing leg occurs one time respectively (for a total of two times), However, if the repo is refinanced over the course of three days, the number of settlements increases to three times for each leg (i.e. to a total of six settlements). 
Figure 24: Kernel Densities
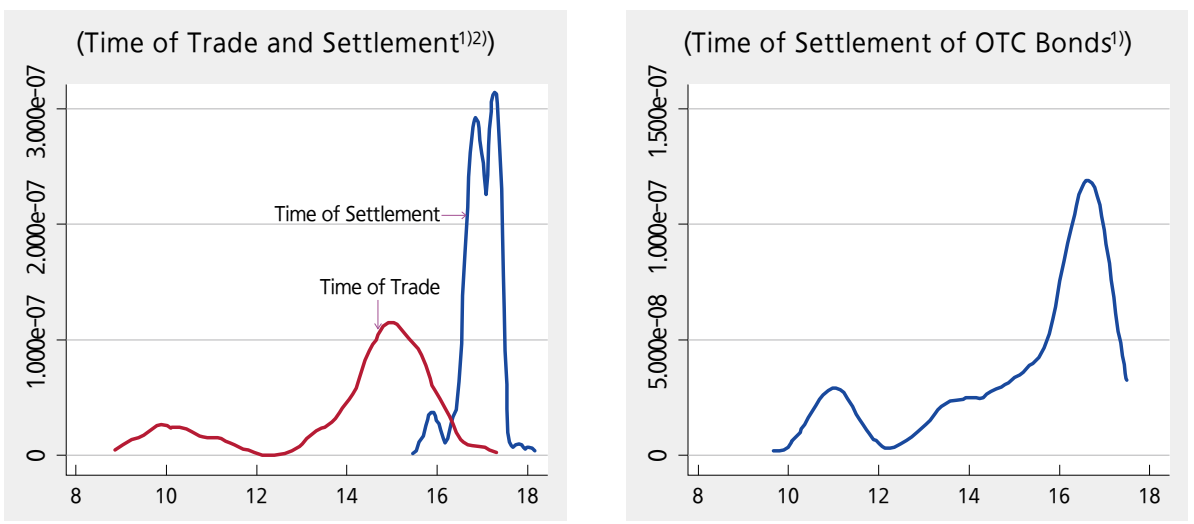

Notes: 1) As of Jan. 2, 2013.

2) Broker-intermediated trade basis.

Sources: BOK, KSD.

\section{Summary and Policy Implications}

During the global financial crisis the US and European repo markets were both generally unstable, partly due to investors' exit. In the stages of crisis development these markets showed differing patterns depending upon the roles of the securities assets used, such as government bonds, and upon the central banks' policy responses.

The US repo markets, whose major participants are securities dealers, responded more sensitively during the initial period of the crisis, and after the crisis broke out, market activity contracted and remained at a low level for a long time. The European repo markets, in contrast, in which banks were the major participants, recovered from the market shocks relatively faster.

Furthermore, the US markets showed high levels of repo rate volatility in line with the supply-demand conditions related to government bonds. The repo rate in Europe on the other hand moved in accordance with overall cash demand, since not only government bonds but also corporate bonds were utilized in the market. 
The repo market in Korea has grown along with the development of the domestic bond market and the increase in pledgeable securities. The market's growth can, in addition, be ascribed to the government's efforts to strengthen the market and its imposition of a cap on the amount of borrowing by securities companies in the call market.

Although no risks arising from the market have yet emerged in practice, thanks in part to its small market volume during the global financial crisis, it could give rise to significant risks due to any drastic reduction in market trading and spread of settlement failures.

For this reason we wish to identify some weak points in the market, and based upon them, suggest some areas for improvement along with lessons from the US and European experiences during the crisis.

First of all, securities companies and securities company trusts, which continue to increase the amounts of their borrowing in the market, are likely to experience a severe drying-up of liquidity during any period of crisis because of their relatively weak financing capacity. To prevent excess borrowing by these financial companies through the repo market, a ceiling on the amount of borrowing needs to be introduced, and banks whose ability to raise funds is stronger should also be encouraged to participate in the market.

Second, when an investor has to sell securities pledged as collateral as a result of a borrower's defaults, the investor may suffer a severe loss if it needs to sell within a short period of time. To prevent such fire-sales the proportion of illiquid collateral should be limited to a certain level, or the establishment of a liquidation facility could be considered.

Third, since repo margin rates are not differentiated by type of collateral, when the market becomes unstable the rollover risks of previous trades can increase overall along with investors' avoidance of illiquid collateral. To lessen such rollover risks, greater differentiation of margin rates in accordance with the types of collateral is called for. However, considering how difficult it will be for individual participants to set these levels, market participants and authorities should work together on the setting of rules instead. Additionally, in order to alleviate the pro-cyclicality of margin rates, the setting of minimum rates should also be considered when intro- 
ducing margin rates.

Finally, given the high proportion of overnight trades and their settlement concentration at around the BOK-Wire closing time, risks that can occur from shortages of settlement liquidity and network system failure are present. For this reason, consideration should also be given to the extension to the repo market of the intraday repo facility introduced in February 2012. 


\section{References}

Bank for International Settlements (2010a), "The Role of Margin Requirements and Haircuts in Procyclicality," CGFS.

(2010b), "Strengthening Repo Clearing and Settlement Arrangements," CPSS.

Begalle, Brian, Antoine Martin, James McAndrews, and Susan McLaughlin (2013), "The Risk of Fire Sales in the Tri-party Repo Market," Federal Reserve Bank of Staff Report No. 616.

Brunnermeier, Markus K. (2009), "Deciphering the Liquidity and Credit Crunch 2007-2008," Journal of Economic Perspectives, 23(1), pp. 77-100.

Chang-Yong Kwak (2012), "Reforms of Settlement Systems of Major Advanced Country Repo Markets," Study on Payment and Settlement, Bank of Korea.

Chang-Yong Kwak, and Sung-guan Yun (2013), "Analysis on Settlement Risk of Repo Markets and Effect of the Introduction of a CCP," Bank of Korea Economic Review, No. 2013-7.

Copeland, Adam, Antoine Martin, and Michael Walker (2010), "The Tri-party Repo Market Before the 2010 Reforms," Federal Reserve Bank of Staff Report No. 477.

(2011), "Repo Runs: Evidence from the Tri-party Repo Market," Federal Reserve Bank of Staff Report No. 506.

Copeland, Adam, Darrell Duffie, Antoine Martin, and Susan McLaughlin (2011), "Policy Issues in the Design of Tri-party Repo Markets," Working Paper. (2012), "Key Mechanics of the US Tri-party Repo Market," FRBNY Economic Policy Review, 18(3), pp. 17-28.

Dang, Tri Vi, Gary Gorton, and Bengt Holmström (2011), "Repo, Haircuts and Liquidity," Working Paper.

European Central Bank (2012), Euro money-market study.

Bank of Korea (2009), Financial Markets in Korea. 
Bank of Korea (2011), Financial Institutions, Markets, and Infrastructure in Korea.

Bank of Korea (2009), Payment System in Korea.

Financial Stability Board (2012), "Market Overview and Financial Stability Issues," Interim Report of the FSB Workstream on Securities Lending and Repos.

Financial Stability Oversight Council (2011), Annual report.

Fleming, Michael and Kenneth D. Garbade (2003), "The Repurchase Agreement Refined: GCF Repo," Federal Reserve Bank of New York, Current Issues in Economics and Finance, 9(6), pp. 1-7.

Garbade, Kenneth, Frank Keane, Lorie Logan, Amanda Stokes, and Jennifer Wolgemuth (2010), "The Introduction of the TMPG Fails Charge for U.S. Treasury Securities," FRBNY Economic Policy Review, 16(2), pp. 45-71.

Gorton, Gary (2012), Misunderstanding Financial Crises: Why We Don't See Them Coming, Oxford University Press.

Gorton, Gary and Andrew Metrick (2011), "Securitized Banking and the Run on Repo,” Journal of Financial Economics, 104(3), pp. 425-451.

Hördahl, Peter and Michael King (2008), "Developments in Repo Markets during the Financial Turmoil," BIS Quarterly Review, December, pp. 37-53.

International Capital Market Association (2012), European repo market survey.

Krishnamurthy, Arvind, Stefan Nagel, and Dmitry Orlov(2012), "Sizing up Repo," NBER Working Paper No. 17768.

Nomura Research Institute (2011), "Measures for the Development of Repo and Securities Lending," Nomura Research Institute. 


\section{$<$ Abstract in Korean $>$}

\section{Sung-guan Yun*, Ronald Heijmans**}

$\mathrm{RP}$ 시장은 무담보시장에 비해 자금회수 측면의 안정성이 높아 견고한 복원력 (resilience)을 가질 것으로 예상되었으나 글로벌 금융위기 기간 중 미국, 유럽 등 주요 선진국에서는 투자자들의 대거 이탈 현상(RP run)이 지속되는 등 불안한 모습을 나타냈다. 구체적으로 당시의 미국과 유럽의 RP시장을 비교하면 거래 규모 및 금리 수준에 있어서 단계별로 서로 다른 변동 패턴을 보였다. 위기 초반 미국의 RP-OIS 금리스프레드는 유럽과 달리 높은 변동성을 기록하고 위기가 심화되면서 유럽과 반대 방향으로 변동하였다. 이러한 상반된 모습은 시장 참가자 구성, 국채 등 담보의 역할, 중앙은행 정책 대응 등이 서로 다른 데 기인한다. BIS 등 국제기구 및 각국 정책당국은 그간의 경험을 기초로 리스크 요인을 분석하고 시장의 안정성을 높이기 위한 작업을 진행 중이다.

국내 기관간 RP시장은 최근 채권시장의 발달과 함께 활용 가능한 담보증권이 늘어나고 정부의 $\mathrm{RP}$ 시장 활성화 대책, 증권사 콜차입 규제 등이 추진되면서 높은 성장세를 지속하였다. 글로벌 금융위기 시에는 시장 규모가 미약하여 문제점이 크게 부각되지 않았으나 앞으로는 거래집중도 증가, 저유동성 담보 확대 및 운영리스크 증대 등으로 취약성을 나타낼 가능성이 있다. 이에 본고는 미국 및 유럽 $\mathrm{RP}$ 시장의 주요 특성과 글로벌 금융위기 경험 등에 비추어 국내 $\mathrm{RP}$ 시장에 잠재된 리스크 요인을 평가하고 개선방향을 도출하였다.

국내시장은 우선 금융기관의 과도한 레버리지 투자를 제한하고 자금조달 능력이 양호한 은행의 참여를 확대할 필요가 있다. 또한 담보자산의 급매 가능성을 낮추기 위해 저유동성 담보가 일정 수준을 넘지 않도록 제한하거나 담보처분장치(liquidation facility)를 도입하는 것이 바람직하다. 아울러 차등화된 증거금률 표준안을 마련하고 일중유동성 지원 제도를 기관간 RP거래에까지 확대하는 방안도 검토할 수 있다.

* Bank of Korea

** De Nederlandsche Bank 